\title{
MOBILE AUDIOBOOKS, LISTENING COMPREHENSION AND EFL COLLEGE STUDENTS
}

\author{
Reima Al-Jarf ${ }^{1}$ (iD \\ ${ }^{1}$ King Saud University, Riyadh, Saudi Arabia
}

\section{ABSTRACT}

This article proposes the integration of mobile audiobooks (MABs) to develop EFL college students' listening comprehension skills. It aims to show the following: (i) The advantages of integrating MABs in listening instruction; (ii) sources of MABs; (iii) how to search for MABs; (iv) criteria for selecting MABs; (v) examples of MABs; (vi) listening comprehension skills and literary appreciation skills that can be developed through supplementary MABs; (vii) phases of teaching and learning with MABs and types of tasks that can be used with MAB; (viii) evaluation and assessment; (ix) the effect of MABs on listening comprehension skill improvement and attitudes as perceived by the students; and ( $\mathrm{x}$ ) recommendations for the effective use of MABs.

Received 6 April 2021

Accepted 21 April 2021

Published 30 April 2021

\section{Corresponding Author}

Reima Al-Jarf, reima.al.jarf@gmail. com

DOI 10.29121/

granthaalayah.v9.i4.2021.3868

Funding: This research received no specific grant from any funding agency in the public, commercial, or not-for-profit sectors.

Copyright: (C) 2021 The Author(s). This is an open access article distributed under the terms of the Creative Commons Attribution License, which permits unrestricted use, distribution, and reproduction in any medium, provided the original author and source are credited.
Keywords: EFL Students, Mobile Listening, Mobile Audiobooks, Listening Comprehension Skills, Oral Discourse, Oral Skill Development

\section{INTRODUCTION}

For a very long time, language teachers and students have been using a variety of technologies to develop students' oral skills such as the utilization of audiobook mobile apps Al-Jarf (2020); extended listening-focused activities after reading and listening to graded audio readers Chang and Millett (2016); MP3 lessons Al-Jarf (2012); podcasts for out-of-class listening practice Abdulrahman et al. (2018); Alm (2013); mobile purposive extensive-podcast-listening and mobile self-regulated podcasts Sendag et al. (2014); podcasts for academic listening in French Weinberg et al. (2011); intercultural talk-radio podcasts Fox (2008); extensive listening using podcasts and vodcasts Faramarzi et al. (2019); Gönülal (2020); student-created videos as a language acquisition strategy Thomas (2017); and audio-cassettes, audio-CDs, portable radios and DVD players Azar and Nasiri(2014).

In addition, thousands of audiobooks (ABs) in a variety of subjects that can be used for developing students' listening comprehension skills are readily available as mobile apps and can be downloaded from the Google Play and Apple Stores. ABs are 
available in many languages and for all ages. They are available in different forms: Audio only, audio and text, and video (audio, motion pictures and music). They are characterized by having professional narrators read the books out loud.

A review of the literature has shown numerous research studies that have used ABs to develop reading and literacy skills while-listening to ABs among elementary, middle school, high school, young adults, and adult students. ABs are used with first (L1) and second language (L2) readers to develop comprehension, expand vocabulary, improve fluency, activate prior knowledge, and increase motivation to interact with books Best et al. (2020); Tusmagambet (2020); Al-Jarf (2019); Milliner (2019); Al-Jarf (2018); Linton and Ph.D. Dissertation, Northcentral University (2017); Moore and Cahill (2016); Lorenzo-Zamorano (2015); Larson (2015); Al-Jarf (2015); Whittingham et al. (2013); Esteves and Whitten (2011); Wolfson (2008); Chen (2004). Furthermore, ABs have traditionally been used in schools by teachers of L2, learning-disabled students, those with reading difficulties, and struggling readers and non-readers. Listening to stories read aloud enhanced children's language skills, made texts accessible particularly those that are beyond the children's decoding skill level or that use old words, nonstandard grammatical structures, expressions, dialects, or foreign names. The differences in voices of characters helped young listeners appreciate humor and provide an annotated bibliography of ABs for K-12 readers and listeners Johnson (2003); Casbergue and Harris (1997).

In Taiwan, 76 EFL college students read and listened to 15 graded texts in a 15-week extensive listening program. They were divided into a control group and three experimental groups (Group 5, n= 30; Group 10, n = 20; Group 15, $\mathrm{n}=26$ ) according to the number of post-listening activities that the experimental groups completed. Results showed that the effect size was very small, medium, and very large on the listening improvement scale for Group 5, 10 and 15 respectively. TOEIC tests showed that Groups 5, 10 and 15 scored 2, 9 and 16 points out of 100 in that order. Only Group 15 showed some transfer effect from narrative to conversational type of listening. The researchers concluded that low-level learners need to read many more texts to make a more significant improvement Chang and Millett (2016).

In the foreign language context, EFL Turkish college students who spent about an hour a week practicing extensive listening with podcasts or vodcasts outside the classroom made significant progress in their overall listening skill development by the end of the academic year. Extensive listening practice with podcasts and vodcasts was highly effective in helping students improve as L2 listeners and they enhanced their pronunciation and vocabulary knowledge. However, the students preferred podcasts to vodcasts. They were occasionally frustrated with the speed of the narrator in the podcasts and vodcasts Gönülal (2020).

In another study, children aged 5, 8, and 10 years old and adults in Germany watched or heard 20 movie scenes or sections of ABs taken or adapted from the TV show Lassie. The children's emotional knowledge and media literacy were evaluated. Results revealed that 5-year-old children made emotional inferences about the protagonist's emotional state in movies while watching movies and listening to ABs simultaneously. Media literacy and emotional knowledge differed in their effect on the children's ability to make inferences, as these depended on children's age and presentation mode Diergarten and Nieding (2015).

Similarly, Iranian EFL students receiving instruction through cell-phone-based ABs outperformed the control group that used the traditional CD-ROM/audio cassette-based ABs on their listening comprehension Azar and Nasiri (2014).

Moreover, listening to ABs had a positive effect, not only on students' listening comprehension skill development, but also on their attitudes towards using ABs in the foreign language classroom. ABs contributed to Turkish freshman students' listening comprehension, pronunciation, motivation, and attitudes Kartal and Simsek (2017). Likewise, $8^{\text {th }}$ 
grade students who listened to ABs had a positive attitude towards listening. The students indicated that ABs can be listened to anywhere. They enrich their imagination and encourage them to use the Internet in a more beneficial way. The students' favorite type of AB was event-themed books. However, the most common disadvantage of ABs was that they did not improve reading speed, did not help with exams, and caused attention deficits Çarkit (2020).

In Saudi Arabia, the literature review showed no studies that investigated the effects of using ABs on EFL college students' listening comprehension skills.

\section{NEED FOR STUDY}

The author conducted an exploratory study in which a needs assessment survey, with open-ended questions was administered to a sample of EFL students in the first 4 levels of the English-Arabic translation program at the College of Languages and Translation (COLT), King Saudi University (KSU), Riyadh Saudi Arabia. A second questionnaire was administered to a sample of instructors at COLT who teach the Listening I, II, III, and IV courses. Results of the needs assessment questionnaire showed that Saudi college students majoring in translation have several listening comprehension difficulties such as: Difficulty identifying main ideas and supporting details in spoken discourse, understanding ideas that are explicitly or implicitly stated in spoken discourse, making predictions andinferences, inferring the meanings of difficult words from the spoken context, and understanding certain syntactic structures in oral discourse such as tenses, participial phrases, idioms, modals, questions, exclamation, passives, emphatic structures, and others. Many struggle to interpret figurative language when encountered in spoken discourse. Some have negative attitudes and feel that English listening activities are difficult and boring. Furthermore, instructors indicated that developing EFL students' appreciation of a literary work, ability to analyze spoken discourse, and general listening comprehension skills are necessary in EFL listening instruction atCOLT.

To develop EFL students' listening skills, many activities such as extensive listening, doing online listening exercises, using mobile listening apps, listening to short stories and simplified novels, and combining listening and reading or listening and speaking activities can be utilized as a supplement to in-class listening instruction that depends on the textbook. Acquiring advanced listening skills is of special importance for EFL students at COLT as they are going to take several simultaneous, consecutive and liaison interpreting courses later in the program which require advanced listening comprehension skills of oral English discourse of all kinds before they convert its meaning to Arabic.

\section{AIMS OF STUDY}

Despite the importance of ABs an MABs in developing EFL college students' listening comprehension skills, results of the exploratory study mentioned above showed that MABs are not being used as an extension listening activity to enhance students' listening comprehension skills. There is also lack of research that investigated the effect of integrating MABs on EFL college students' listening comprehension in the Saudi context. Therefore, this study proposes the utilization of MABs as an out-of-class extension activity, i.e., as a supplement to in-class listening instruction that depends on the textbook to enhance students' listening comprehension skills. It aims to: (i) give examples of MABs; (ii) give advantages of using MABs; (iii) sources of MABs; (iv) show how to search for and select MABs; (v) identify listening comprehension and literary appreciation skills that can be developed with MABs; (vi) describe instructional stages with MABs; (vii) describe MABs listening comprehension evaluation and assessment; (viii) define the role of the instructor; (ix) show the effect of MABs on learning and attitudes as perceived by the students; and (x) give some recommendations for the effective use of MABs. 
The use of MABs as an extension activity or as a supplement to in-class instruction in ESL/EFL has many benefits. MABs are free. They are easy and quick to download and uninstall. They can be used anywhere, anytime and can be re-played many times. They have different difficulty levels, lengths, and genres. The students can listen to stories, novels, plays, motivational and self-help books in the American or British accent. They can choose between audio only, audio and text and audio, motion pictures and music. The narrator reads with intonation and good expression which will help the students understand better and visualize the events and characters in the book being read. They can listen to the book chapters one at a time, listen to several chapters or the whole book.

\section{MATERIALS AND TASKS AND INSTRUCTIONAL PHASES}

\subsection{LOCATING AND SEARCHING FOR MABS}

The instructor and/or the students can search for MABs using search terms such as "audiobooks" "English audiobooks", “English stories audiobooks", "literature audiobooks", “audiobook libraries", "self-improvement audiobooks" and so on. They can search Google, Google Play, or Apple Store for audiobook libraries as in the following examples:

- Disney audiobooks (YouTube videos)

- Ossys audiobooks

- Short classic audiobooks

- Librivox English Audiobooks (audio and text)

- Audiobooks (the 2,800 classics audiobooks)

- Kobo Books - eBooks \& Audiobooks

- Audiobooks from Tocalivros

- Beelinguapp: Learn Languages Music and Audiobooks

- Pustaka - Ebooks and Audiobooks

- LibriVox Audio Books

- Audiobooks.com Listen to new audiobooks and podcasts

- 50000 Free eBooks \& Free AudioBooks

- Audible: audiobooks, podcasts \& audio stories

- English Stories - Audio Books Offline Free

- Free Classic Audiobooks - Read and listen

- Listen AudioBooks

- Free Books and Audiobooks

- Motivational \& Inspirational Audiobooks

- Audiobook Library

- Audiobooks for English Language Learners 


\subsection{CRITERIA FOR SELECTING MABS}

In selecting MABs for students in a particular college level, the instructor and/or students are advised to use one MAB at a time. The MAB selected should match the students' proficiency level, familiarity with the topic, students' interests, the MAB length and difficulty level, and the speed and accent of the narrator. The instructor should select the mode of practice needed: Audio only, audio and text, or audio and video. She may look at the user ratings and their comments on the MAB. She should listen to the whole MAB or parts of it before assigning it to the students.

\subsection{LISTENING COMPREHENSION SKILLS THAT CAN BE DEVELOPED WITH MABS}

- Understanding the main idea and supporting details.

- Identifying the plot, setting, characters, theme, point of view, imagery, symbolism, style and tone, and figurative language in a short story, novel, or play.

- Deriving meaning of difficult words from contextual and structural clues in the spoken context.

- Understanding anaphoric relationships in the spoken discourse.

- Connecting information in the spoken discourse with the students' prior knowledge.

- Making predictions from the main title (heading).

- Understanding the organizational structure of the spoken discourse (chronology, enumeration, analogy, causeeffect, classification, compare/contrast, chole/part, process), and identifying organizational clues, and transitional words,

- Focusing on content words, figures, dates, statistics, and other details.

- Making an outline of the main topics and sub-topics in the MAB or part ofit.

\subsection{INSTRUCTIONAL PHASES WITH MABS}

\subsubsection{PRE-LISTENING PHASE}

In this phase, introduce the MAB to be used. Tell the students how to download it. Give pre-questions to help the students focus on the main ideas and supporting details or the story elements: Theme, setting, plot, characters, style, and tone ... etc. Post the questions on an online discussion forum, blog, or Facebook Page. Set a time limit or a deadline for completing a task (1-2 weeks). The following are examples of pre-questions that can beasked:

To identify the book author and date, ask:

- Who is the author?

- Where is the author from?

- When was the book written?

- When was the book published?

To identify the theme of the book, ask:

- What is the whole book about?

- What is the theme, i.e., main idea of the book?

- What does the theme say about the world, human experience, or humanvalues?

- Why did the author write the book? 
- What message, moral or lesson do you get or understand from the book?

To identify the characters, ask:

- Who is the protagonist in the story?

- Make a list of the characters in the story.

To identify the setting, ask:

- Where does the story take place?

- Which time period is it? Is the story about the past or present?

- What is the setting in the story and how does it contribute to it?

- What is the mood in the story and how does the setting affect the mood?

To identify the plot, ask:

- Make a list of the main events in the story?

- Are these events in chronological order? Do they flash back or forward?

- What is the main conflict in the story?

- What is the turning point in the story?

- How does the author create suspense in the story?

To identify the viewpoint, ask:

- Is the point of view subjective or objective?

- Who is narrating the story: The protagonist or an observer of the events?

- Is the tone formal, informal, funny, sarcastic, or sad?

To analyze the tone and style, ask:

- Is the style formal or informal?

- Does the author use standard non-standard language?

- What types of sentences does the author use (simple, compound, complex, exclamatory, passive, rhetorical, fragments)?

- Is the tone in the story sad, sarcastic, humorous...etc.?

To identify any figurative language, ask:

- Give examples of the use of imagery (similes, metaphors, hyperbole, synecdoche, personification ...etc.)?

- Is there symbolism in the story? Give examples?

\subsubsection{WHILE LISTENING}

While listening to a MAB, the students take notes. They post their responses to the questions on an online discussion forum, blog, or Facebook page. They summarize the book in one or more pages and post their summaries in the forum. They post comments on each other's responses. They discuss the elements of the novel or book under the instructor's supervision. 


\subsubsection{POST-LISTENING}

After listening to a MAB, give feedback, comment on the students' performance. Provide guidance especially if the MAB is difficult. Answer students' questions, encourage them to try and provide help with errors and difficulties.

\subsection{EVALUATION AND ASSESSMENT}

On listening interm tests and final exams, the students may listen to an excerpt from a MAB that they have not listened to before, followed by some listening comprehension questions selected from the examples above.

\subsection{INSTRUCTOR'S ROLE}

The listening instructor serves as a facilitator. She helps the students search for and download the MABs. She follows the students up to make sure they are comprehending and are able to follow the MAB under study. She encourages the students to suggest MABs of interest to them. She gives extra credit for participation and answering the questions. The instructor might assign a number of MABs to match the ability level of the students in the group, some easy, some of medium difficulty and some advanced. The students keep a log of the MABs they have listened to, and they are given extra credit according to the number of MABs they have finished.

\section{REFLECTIONS}

Effectiveness of the MAB instruction is supported by results of the prior studies mentioned above in which the students practiced listening comprehension with ABs and other technologies such as Chang and Millett (2016); Diergarten and Nieding (2015); Diergarten and Nieding (2015); Al-Jarf (2012); Azar and Nasiri (2014); Johnson (2003); Casbergue and Harris (1997) and others.

Furthermore, the author used the instructional strategies outlined in this article in teaching listening comprehension to EFL college students at COLT. At the end of the semester, the students' responded to a questionnaire. Responses to the questionnaire showed that the students had positive attitudes towards practicing listening comprehension with MABs. They found the MABs fun, and they enjoyed analyzing the books, short stories, and novels they listened to. They reported that use of supplementary listening comprehension exercises with MABs had several advantages: They met students' needs and catered for differences in listening comprehension ability and experiential level among the students, targeted their listening comprehension weaknesses such as inferring meanings of difficult words from context, understanding some grammatical structures and inferring the topic and moral in a story. Students who struggled with listening to the textbooks' audios indicated that MABs provided them with extra opportunities for practicing listening comprehension tasks and exercises that they could manage. Practice with MABs helped them acquire cognitive and metacognitive listening comprehension skills as the task depended on spoken text analysis, making lots of inferences and learning about the different aspects of oral English. Some of the students' responses to the questionnaire were:

Mira: listening to MABs is a new way of practicing listening comprehension that I find interesting and fun, unlike long texts in the textbook.

Rania: I found MABs and exercises that match my listening comprehension skill level and explanations that I could understand, unlike the textbook audios that all students had to use whether they understand them or not.

Salwa: With MABs and interactive listening comprehension tasks, I did extra exercises that helped me overcome my difficulty in inferring meanings of difficult words from the spoken context, inferring the general theme and lesson learnt from a story. 
Hana: The extra listening comprehension practice with MABs helped enhance my ability to analyze the text I listened to, especially the components of a story.

Hanoof: MABs with listening comprehension exercises provided me with extra practice and helped me focus on specific aspects of the language because the simplified novels I listened to were interesting to follow.

Utilization of MABs showed improved students' listening comprehension, literary appreciation, and literary analysis skills. It also revealed increased student engagement. The students enjoyed listening to MABs. They reported that video MABs were the easiest and the audio only MABs were the most difficult, because the pictures helped them understand the content.

Students' responses revealed some challenges such as difficulty in following and understanding the narrator. Some narrators were speaking fast. They had difficulty understanding some narrators' accent. Some students found it difficult to listen to audio and follow the text especially at the beginning of the semester. This finding is also consistent with findings of Gönülal (2020) study with Turkish students.

\section{RECOMMENDATIONS}

The present study recommends the integration on MABs as a supplement to in-class listening courses at COLT. For best results, this study recommends that the listening instructor select simplified and short audiobooks, proceed gradually from video to audio with text, then audio only. Similarly, the students may proceed gradually from familiar children's stories to short stories, simplified novels, then longer novels and books.

The students should not be left on their own and should never listen to a MAB passively. They should have some tasks to work on during and after listening to a MAB. They should pay attention to the theme, characters, plot setting, specific vocabulary, imagery, figures of speech, and grammatical structures in a MAB. They can practice inferring the theme, giving the morale or lesson learnt and retell/summarizing the overall MAB they have listened to. Students who do not possess a smart phone, may search Google for another version of the same MAB and listen to it on their laptop.

Since there are thousands of MAB apps, the author recommends that a MAB repository be especially created by EFL instructors and students at COLT in which a sample of relevant MABs are stored and classified according to author, theme, and source. A comprehensive alphabetical index can be added to the repository to facilitate the searching process and to allow EFL instructors and students to access the MABs of interest to them easily and quickly. Listening comprehension questions on each MAB can be added. The online MAB repository should be interactive. Students should be able to answer listening comprehension questions, post answers and receive feedback from their instructors. MABs used should be constantly reviewed and updated, with new MABs added and uninteresting or overused ones removed. Those are believed to enhance EFL college students' listening comprehension skills in language and translation schools.

\section{REFERENCES}

Abdulrahman, T., Basalama, N., \& Widodo, M. R. (2018). THE IMPACT OF PODCASTS ON EFL STUDENTS' LISTENING COMPREHENSION. International Journal of Language Education, 2(2), 23-23. Retrieved from https://dx.doi.org/10.26858/ ijole.v2i2.5878 10.26858/ijole.v2i2.5878

Al-Jarf, R. (2012). Mobile Apps in The EFL College Classroom. Mobile Technology and Student Autonomy in Oral Skill Acquisition". In Javier E. Díaz Vera's Innovation and Leadership in English Language Teaching, 105-130. 
Al-Jarf, R. (2015). Enhancing Reading and Speaking Skills in EFL Through Multicultural Children's Short Stories. In 7th International Conference Building Cultural Bridges (ICBCB).

Al-Jarf, R. (2018). Effect of Background Knowledge on Auditory Comprehension in Interpreting Courses (R. Jancarikova, Ed.). Brno, Czech Republic: Muni Press.

Al-Jarf, R. (2019). Teaching Reading to EFL freshman Arabic Students Online. Eurasian Arabic Studies, 8, 57-75.

Al-Jarf, R. (2020). Mobile Apps in The EFL College Classroom". Journal for Research Scholars and Professionals of English Language Teaching (JRSP-ELT), 4(22), 1-5.

Alm, A. (2013). Extensive Listening 2.0 With Foreign Language Podcasts. Language Learning and Teaching, 7(3), 266-280.

Azar, A. S., \& Nasiri, H. (2014). Learners' Attitudes toward the Effectiveness of Mobile Assisted Language Learning (MALL) in L2 Listening Comprehension. Procedia - Social and Behavioral Sciences, 98(6), 1836-1843. Retrieved from https://dx.doi.org/ 10.1016/j.sbspro.2014.03.613 10.1016/j.sbspro.2014.03.613

Best, C., Clark, I., \& Picton. (2020). Children, Young People and Audiobooks Before and During Lockdown". National Literacy Trust Research Report. ERIC Number ED607856.

Çarkit, C. (2020). Evaluation of Audiobook Listening Experiences Of 8th Grade Students: An Action Research. Educational Policy Analysis and Strategic Research, 15(4), 146-163.

Casbergue, R., \& Harris, K. (1997). A Summer of Stories: Audiobooks for Family Listening. Book Links, 6(6), 56-60.

Chang, A. C.-S., \& Millett, S. (2016). Developing L2 Listening Fluency through Extended Listening-focused Activities in an Extensive Listening Programme. RELC Journal, 47(3), 349-362. Retrieved from https://dx.doi.org/10.1177/ $003368821663117510.1177 / 0033688216631175$

Chen, S. H. (2004). Improving Reading Skills Through Audiobooks". School Library Media Activities Monthly, 21(1), 22-25.

Diergarten, A., \& Nieding, G. (2015). Children's and Adults' Ability to Build Online Emotional Inferences During Comprehension of Audiovisual And Auditory Texts". Journal of Cognition and Development, 16(2), 381-406.

Esteves, K. J., \& Whitten, E. (2011). Assisted Reading with Digital Audiobooks for Students with Reading Disabilities. Assisted Reading with Digital Audiobooks for Students with Reading Disabilities". Reading Horizons, 51, 21-40.

Faramarzi, S., Tabrizi, H. H., A, \& Chalak. (2019). The Effect of Vodcasting Tasks on EFL Listening Comprehension Progress in An Online Program". International Journal of Instruction, 12(1), 1263-1280.

Fox, A. (2008). Using podcasts in the EFL classroom. TESL-EJ, 11(4).

Gönülal. (2020). Improving Listening Skills with Extensive Listening Using Podcasts and Vodcasts". International Journal of Contemporary Educational Research, 7(1), 311-320.

Johnson, D. (2003). Audiobooks: Ear-resistible. Audiobooks: Ear-resistible!” Reading Online, 6.

Kartal, G., \& Simsek, H. (2017). The Effects of Audiobooks on EFL Students' Listening Comprehension. The Effects of Audiobooks on EFL Students' Listening Comprehension." Reading Matrix: An International Online Journal, 17, 112-123.

Larson, L. C. (2015). E-books and Audiobooks: Extending the Digital Reading Experience. Reading Teacher, 69(2), 169-177.

Linton, S., \& Ph.D. Dissertation, Northcentral University. (2017). A Qualitative Case Study of Reading-While-Listening to Audiobooks Simultaneously. A Qualitative Case Study of Reading-While-Listening to Audiobooks Simultaneously, 580015-580015.

Lorenzo-Zamorano, S. (2015). Sound Literature: The Pedagogy of Reconnection Through Student-Authored Audiobooks in The Spanish Curriculum. Research-publishing.net. ERIC Number: ED577065.

Milliner, B. (2019). Comparing Extensive Reading to Extensive Reading-While-Listening on Smartphones: Impacts on Listening and Reading Performance for Beginning Students. Reading Matrix: An International Online Journal, 19(1), 1-19.

Moore, J., \& Cahill, M. (2016). Audiobooks: Legitimate "Reading" Material for Adolescents? School Library Research, 19.

Sendag, S., Caner, M., \& Kafes, H. (2014). Mobile Purposive-Extensive-Podcast-Listening Versus Mobile Self-Regulated-PodcastDevelopment: A Critical Framework for Designing Foreign Language Listening. In EUROCALL Conference.

Thomas, S. J. (2017). Student-Created Videos as A Language Acquisition Strategy for a Haitian Learner. Student-Created Videos as A Language Acquisition Strategy for a Haitian Learner, 583417-583417.

Tusmagambet, B. (2020). Effects of Audiobooks on EFL Learners' Reading Development: Focus on Fluency and Motivation. ENGLISH TEACHING, 75, 41-67. Retrieved from https://dx.doi.org/10.15858/engtea.75.2.202006.41 10.15858/engtea .75 .2 .202006 .41

Weinberg, A., Knoerr, H., \& Vandergrift, L. (2011). Creating Podcasts for Academic Listening in French: Student Perceptions of 
Enjoyment and Usefulness. CALICO Journal, 28(3), 588-605. Retrieved from https://dx.doi.org/10.11139/cj.28.3.588-605 $10.11139 /$ cj.28.3.588-605

Whittingham, J., Huffman, S., Christensen, R., \& Mcallister, T. (2013). Use of Audiobooks in A School Library and Positive Effects of Struggling Readers' Participation in A Library-Sponsored Audiobook Club. School Library Research, 16.

Wolfson, G. (2008). Using Audiobooks to Meet the Needs of Adolescent Readers. Using Audiobooks to Meet the Needs of Adolescent Readers". American Secondary Education, 36, 105-117.

\section{APPENDIX}
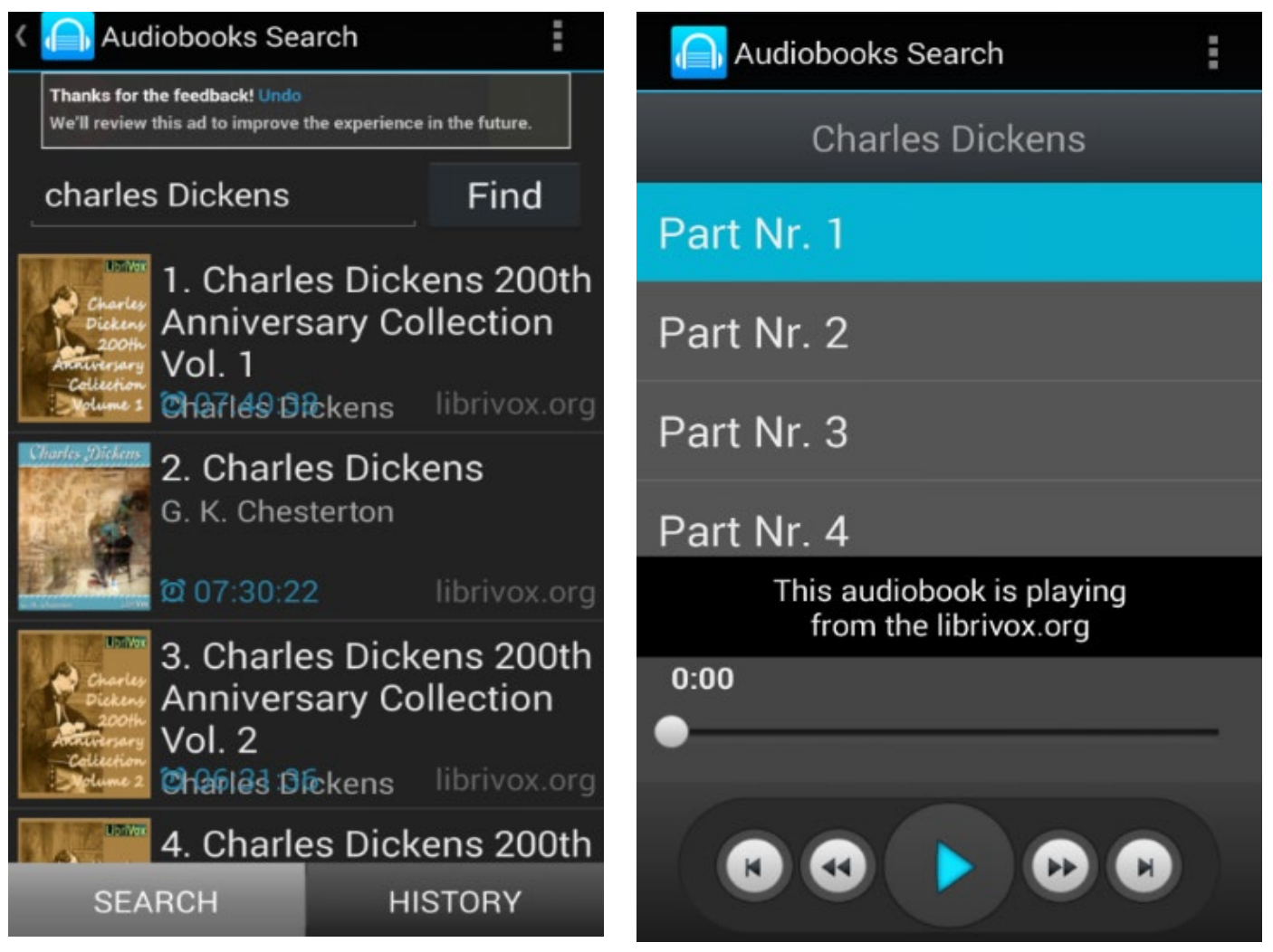

Images 1 Audiobook Search App 


\begin{tabular}{|c|c|c|}
\hline ck & By Genre & Audio Books Free \\
\hline & Adventure & Ton $10 \wedge$ ind: \\
\hline & Advice & All-Time \\
\hline & Ancient Texts & Classics \\
\hline & Animals & arch Milliol \\
\hline & Art & Frep Audin Rnnks \\
\hline & Biography & Do Children's Classics! \\
\hline & Children & new New Release Free \\
\hline & Classics (antiquity) & oks \\
\hline & Comedy & iction \\
\hline & Cookery & $8 P^{2}$ \\
\hline & Economics/Political & \\
\hline & Epistolary fiction & Mark 1 \\
\hline
\end{tabular}

Images 2 Searching for Specific Audiobooks

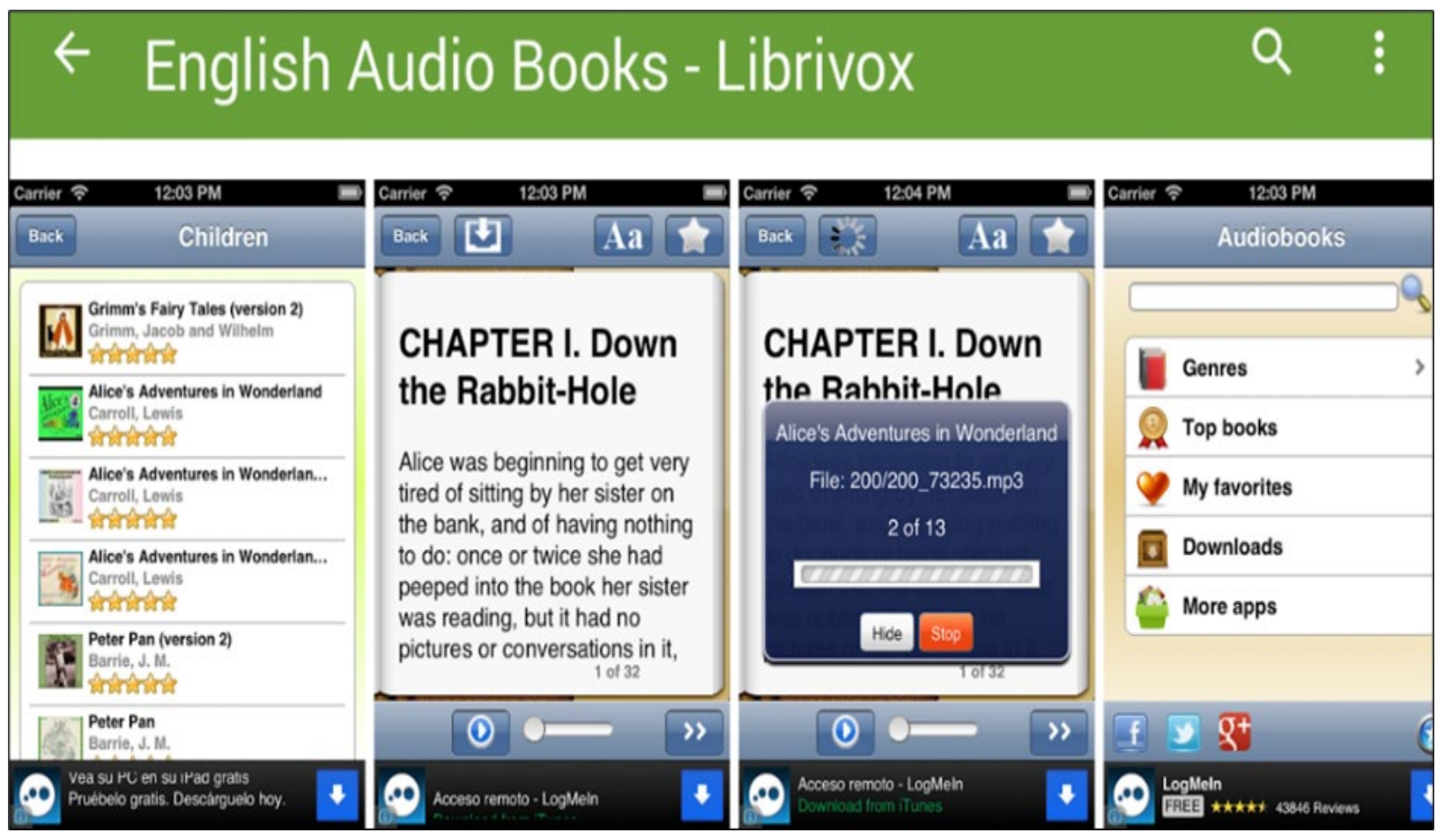

Image 3 Searching for an Audiobook Library 


A Christmas Carol
by Charles Dickens
Animal Farm
by George Orwell
by Maurice Leblanc
by Jack London
Ethan Frome
by Edith Wharton
brankenstein
by Mary Shelley

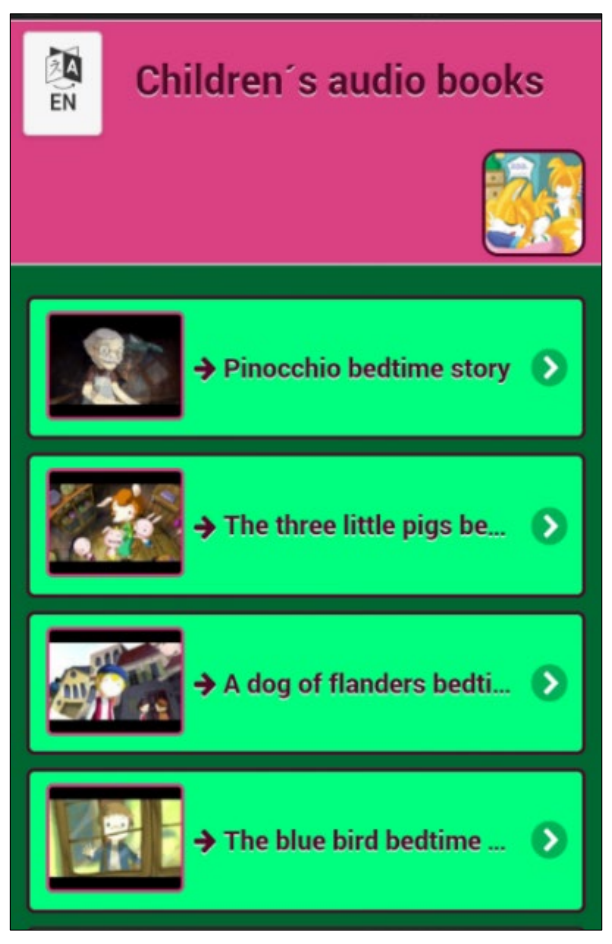

\begin{tabular}{|c|c|}
\hline Back & Aa \\
\hline \multirow{2}{*}{\multicolumn{2}{|c|}{ Mowgli's Brothers }} \\
\hline & \\
\hline & $\begin{array}{l}\text { Now Rann the Kite bring } \\
\text { That Mang the Bat s€ } \\
\text { The herds are shut in } t \\
\text { For loosed till dawr } \\
\text { This is the hour of pri } \\
\text { Talon and tush and c } \\
\text { Oh, hear the call!-Gooc } \\
\text { That keep the Jungle } \\
\text { Night-Song in the Jungl }\end{array}$ \\
\hline & $\begin{array}{l}\text { as seven o'clock of a very warm } \\
\text { ing in the Seeonee hills when } \\
\text { er Wolf woke up from his day's } \\
\text { scratched himself, yawned, and } \\
\text { ad out his paws one after the } \\
1 \text { of } 26\end{array}$ \\
\hline
\end{tabular}

Images 4 Examples of Audiobook Libraries: Short Classic Audiobooks (left) \& Children's Audiobooks (right)

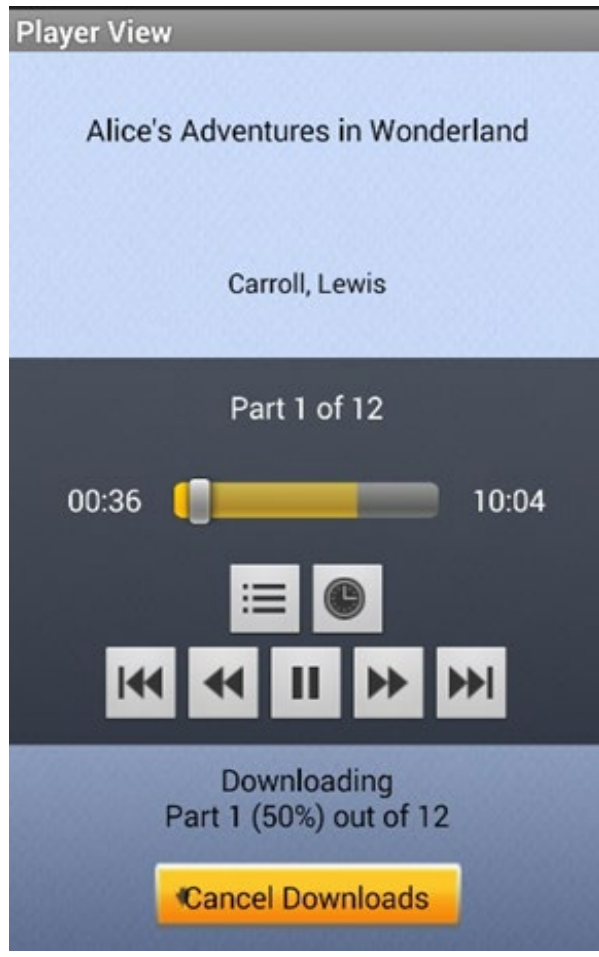

Image 6 Audio Only
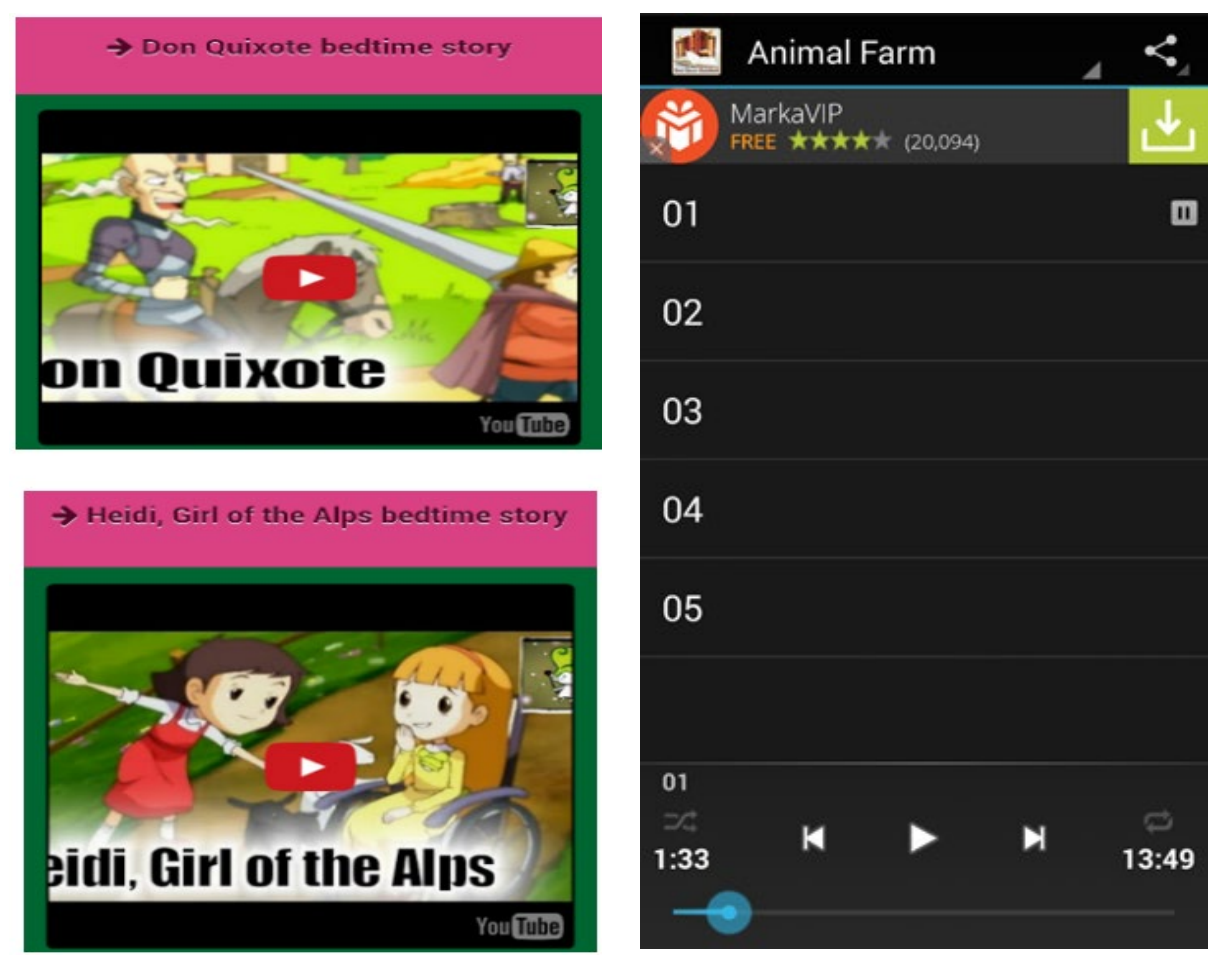

Images 7 YouTube videos
01

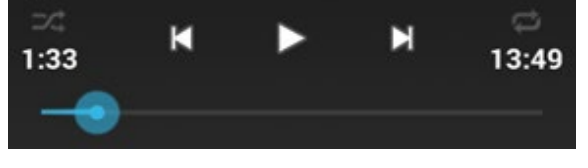

Image 8 Audio only
Image 5 Audio \& text 


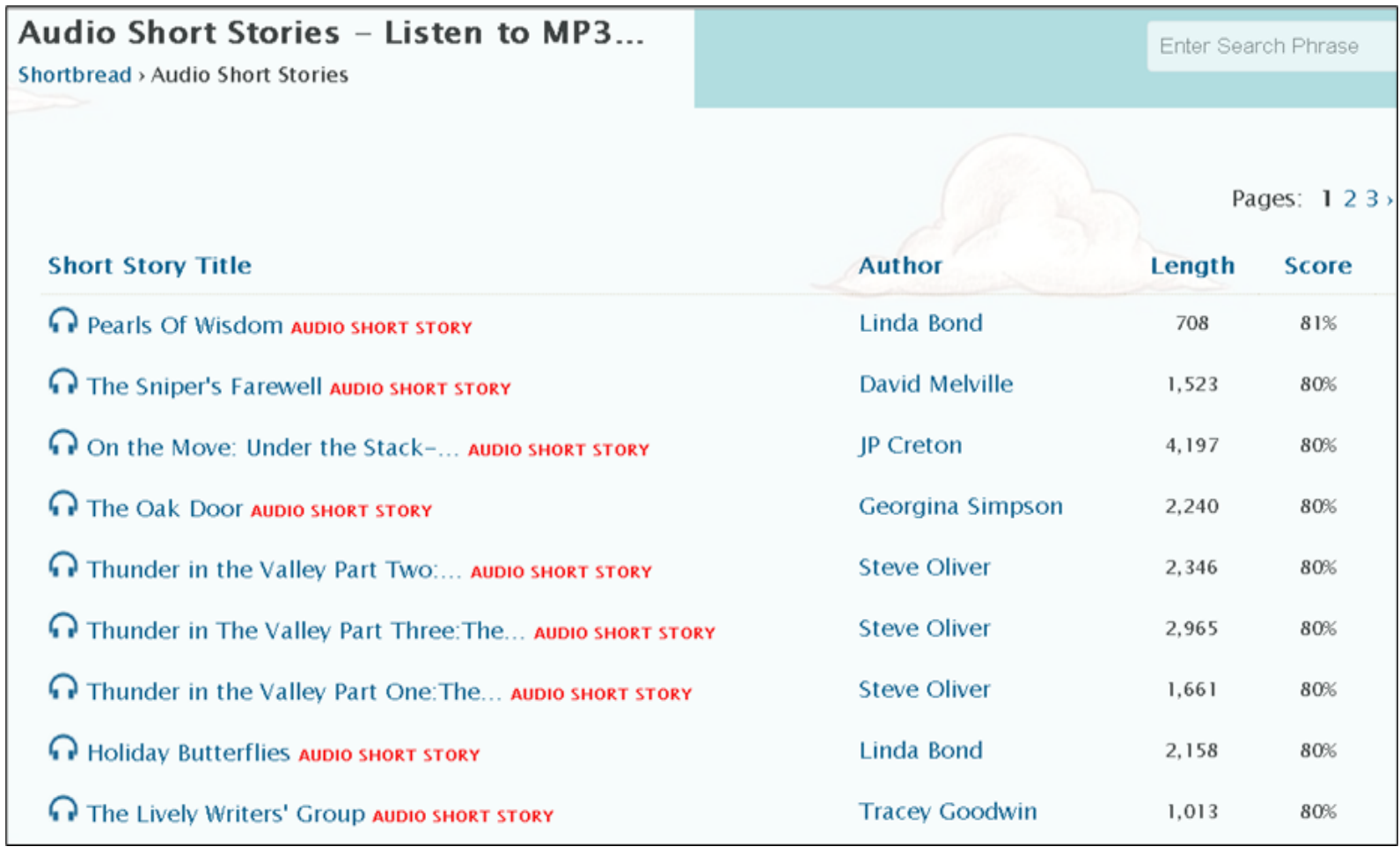

\section{Image 9 Audio Only Short Stories}

About this Short Story
"Yoo hoo! Grandmal It's only me!" Rosa called, bustling into the light and warmth of the
Litten by
Rosa visits her grandma in her
cottage in the woods. But is
grandma all she seems?
"Maul Jerricho
Fantasy short stories
Thriller short stories
Whimsical short stories

Image 10: Sample Short Story with Audio and Text 


\section{AUTHOR BIOGRAPHY}

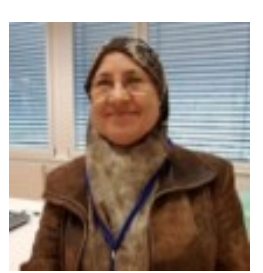

Reima Al-Jarf is professor of ESL, ESP, and translation. She has 700 publications and conference presentations in 70 countries. Some of her articles are published in Web of Science and Scopusindexed journals. She reviews Ph.D. theses, promotion works, conference and grant proposals, and articles for numerous peer-reviewed international journals including some Web of Science and

Scopus-indexed journals. She won 3 Excellence in Teaching Awards, and the Best Faculty Website Award at her university. Her areas of interest are: Foreign language teaching and learning, technology integration in education and translation studies. 